๑I. М. Нікітіна

Сумсъкий державний університет, Суми

\title{
ОСОБЛИВОСТІ БІОЦЕНОЗУ ТА ФУНКЦІОНАЛЬНОЇ АКТИВНОСТІ ВАГІНАЛЬНОГО ЕПІТЕЛІЮ ПРИ МІСЦЕВОМУ ЛІКУВАННІ НЕСПЕЦИФІЧНОГО ВАГIHITУ
}

Мета дослідження - оцінити клінічну та мікробіологічну ефективність і безпечність застосування препарату «Кломезол» у лікуванні неспецифрічного вагініту.

Матеріали та методи. Для вирішення поставленого завдання проведено обстеження і лікування 60 жінок репродуктивного віку з діагнозом аеробного вагініту. Проведено оцінку клінічної та мікробіологічної ефрективності терапії у пацієнток з аеробним вагінітом. Вивчено терміни зникнення об'єктивних і суб'єктивних симптомів запального процесу, особливості функціональної активності епітелію піхви, вплив препарату на стан нормальної мікрофрлори піхви. Дослідження проведено відповідно до міжнародних нормативів і правил GCP.

Результати дослідження та їх обговорення. У результаті проведеного дослідження було встановлено, що комбінований препарат «Кломезол» у вигляді вагінальних свічок $є$ есрективним по відношенню до умовно-патогенних мікроорганізмів збудників аеробного вагініту і є препаратом вибору для лікування бактеріального вагінозу та аеробного вагініту. Кломезол не здійснює імуносупресивного впливу на епітелій піхви, завдяки цьому відновлення фрункціональної активності епітелію після лікування кломезолом відбувається швидше, ніж після лікування тержинаном. Відмічено покращення якості життя пацієнток після лікування.

Висновки. Відмічена висока есрективність комбінованого препарату «Кломезол» по відношенню до широкого спектра мікрофрлори, доведена висока терапевтична активність та безпечність у використанні у пацієнток з аеробними вагінітами. Кломезол добре переноситься та не викликає резистентності мікрофрлори. Препарат може використовуватись у II і III триместрах вагітності.

Ключові слова: аеробний вагініт; бактеріальний вагіноз; кломезол; лікування; багатоцентрове рандомізоване контрольоване дослідження.

ОСОБЕННОСТИ БИОЦЕНОЗА И ФУНКЦИОНАЛЬНОЙ АКТИВНОСТИ ВАГИНАЛЬНОГО ЭПИТЕЛИЯ ПРИ МЕСТНОМ ЛЕЧЕНИИ НЕСПЕЦИФИЧЕСКОГО ВАГИНИТА

Цель исследования - оценить клиническую и микробиологическую эффективность и безопасность применения препарата «Кломезол» в лечении аэробного вагинита.

Материалы и методы. Для решения поставленной задачи проведено обследование и лечение 60 женщин репродуктивного возраста с диагнозом аэробного вагинита. Проведена оценка клинической и микробиологической эффективности терапии у пациенток с аэробным вагинитом. Изучены сроки исчезновения объективных и субъективных симптомов воспалительного процесса, особенности срункциональной активности эпителия влагалища, влияние препарата на состояние нормальной микросрлоры влагалища. Исследование проведено в соответствии с международными нормативами и правилами GCP.

Результаты исследования и их обсуждение. В результате проведенного исследования было установлено, что комбинированный препарат «Кломезол» в виде вагинальных свечей является эффрективным по отношению к условно-патогенным микроорганизмам - возбудителям аэробного вагинита и является препаратом выбора для лечения бактериального вагиноза и аэробного вагинита. Кломезол не осуществляет иммуносупрессивного воздействия на эпителий влагалища, благодаря этому восстановление фрункциональной активности эпителия после лечения кломезолом происходит быстрее, чем после лечения тержинаном. Отмечено улучшение качества жизни пациенток после лечения.

Выводы. Отмечена высокая эфрфективность комбинированного препарата «Кломезол» по отношению к широкому спектру микрофлоры, доказана высокая терапевтическая активность и безопасность в использовании у пациенток с аэробными вагинитами. Кломезол хорошо переносится и не вызывает резистентности микрофлоры. Препарат может использоваться во II и III триместрах беременности.

Ключевые слова: аэробный вагинит; бактериальный вагиноз; кломезол; лечение; многоцентровое рандомизированное контролируемое исследование.

PECULIARITIES OF BIOCENOSIS AND FUNCTIONAL ACTIVITY OF VAGINAL EPITHELIUM IN LOCAL TREATMENT OF NONSPECIFIC VAGINITIS

The aim of the study - to evaluate the clinical and microbiological effect and safety of the drug Clomezol in the treatment of aerobic vaginitis.

Materials and Methods. To solve this problem, 60 women of reproductive age were diagnosed and treated with aerobic vaginitis. The clinical and microbiological effect of therapy in patients with aerobic vaginitis was evaluated. The time of disappearance of objective and subjective symptoms of the inflammatory process, features of the functional activity of the vaginal epithelium, the effect of the drug on the state of the normal microflora of the vagina were studied. The study was conducted in accordance with international regulations and GCP rules.

Results and Discussion. As a result of the study, it was found that the combined drug Clomezol in the form of vaginal suppositories is effective against opportunistic microorganisms - causative agents of aerobic vaginitis and is the drug of choice for 
the treatment of bacterial vaginosis and aerobic vaginitis. Clomezol does not perform immunosuppressive effects on the vaginal epithelium, due to this, the restoration of functional epithelium after tratment with Clomizol occurs faster than after treatment with Tergynan. Improved quality of life of patients after treatment of nonspecific vaginosis was noted.

Conclusions. High efficacy of the combined Clomezol drug against a wide spectrum of microflora was noted, high therapeutic activity and safety in use in patients with aerobic vaginitis was demonstrated. Clomezol is well tolerated and does not cause microflora resistance. The drug can be used in the II and III trimesters of pregnancy.

Key words: aerobic vaginitis; bacterial vaginosis; Clomezol; treatment; multicenter randomised controllable reserch.

ВСтуп. Вагінальна екосистема характеризується поліморфною ендогенною мікрофрлорою, якісний і кількісний склад якої є надзвичайно нестабільною величиною і залежить від впливу ендогенних та екзогенних фракторів. Будьяка зміна вагінальної екосистеми - принциповий фрактор ризику для розвитку найбільш поширених інфекцій нижнього відділу статевого тракту: бактеріального вагінозу (БВ), кандидозного, протозойного та неспецисрічного вагінітів. Вагініти є інфекційними захворюваннями піхви, найбільш часто зустрічаються в структурі гінекологічної патології. Етіологічними агентами вагінітів можуть виступати як патогенні, так і умовно-патогенні мікроорганізми [1]. При цьому серед клінічних фрорм вагінітів (вульвовагінітів) найбільше значення мають такі захворювання: бактеріальний вагіноз (30-50 \%), кандидозний вагініт (30-45 \%) і трихомонадний вагініт (10-20 \%, у країнах, що розвиваються, - до 40 \%). Досить часто зустрічаються змішані інорекційні захворювання піхви (10-30 \%) [2]. Бактеріальний вагіноз - це не що інше, як дисбактеріоз вагінального біотопу. При бактеріальному вагінозі відбувається повне або часткове заміщення лактобацил (менше 10 в 4 ступені КУО / мл) анаеробними бактеріями i Gardnerella vaginalis. Для БВ характерна масивна (більше 10 в 9 ступені КУО / мл) полімікробна забрудненість вагінального біотопу (Mobilincus spp., Bacteroides spp., Peptostreptococcus spp., Fusobacterium spp.). Встановлення діагнозу бактеріального вагінозу ґрунтується на наявності характерних вагінальних виділень (рідкі, гомогенні, білі) 3 неприємним «рибним» запахом і підтвердженні даними кольпоскопічного дослідження. Часто бактеріальний вагіноз перебігає безсимптомно (24-25 \%) [3]. Бактеріальний вагіноз є клінічним синдромом, який може виникнути при різних захворюваннях, у т. ч. і при кандидозі і трихомоніазі. У свою чергу, бактеріальна умовно-патогенна фрлора завдяки високій ферментативній і літичній активності створює умови для проникнення грибів у тканини. Бактеріальний вагіноз не відноситься до дійсних захворювань, що передаються статевим шляхом. Кандидозний вульвовагініт викликається дріжджоподібними грибами роду Candida albicans. Клінічне значення мають і інші види грибів: C. glabrata (5-10\%), C. tropicalis (3-5\%), C. parapsilosis (3-5\%), C. krusei (1-3\%). В останні роки зросла поширеність С. glabrata, для якої характерні розвиток хронічних рецидивуючих фрорм, стійкість до лікування і найбільш часте виявлення у хворих, які страждають від цукрового діабету. Кандидозний вульвовагініт не належить до захворювань, що передаються статевим шляхом. Дріжджоподібні гриби роду Candida $\epsilon$ умовно-патогенними мікроорганізмами і можуть бути присутніми в піхві у здорових жінок (10-20 \%) в концентрації, що не перевищує 10 в 4 ступені КУО / мл (при домінуванні в складі мікробних асоціацій лактобацил), що розцінюється як кандиданосійство. Виділяють гострий (до двох місяців) і хронічний вульвовагініт (більше двох місяців). Для кандидозного вульвовагініту характерні такі клінічні ознаки: свербіж, еритема, патологічні виділення білого кольору, сирнисті за характером, дизурія, набряк вульви і слизової піхви. Клінічні прояви посилюються в передменструальний період і після статевого акту. При мікроскопічному дослідженні виділень піхви визначають гриби роду Candida у вигляді бластоспор і ниток міцелію, а також мікросрлору, характерну для нормального вагінального біотопу. При бактеріологічному дослідженні при істинному кандидозному вульвовагініті визначають високий титр грибів роду Candida (більше 10 в 4 ступені КУО / мл) і лактобацил (більше 10 у 6 ступені КУО / мл) при відсутності діагностично значимих титрів будь-яких інших умовно-патогенних мікроорганізмів. Часто зустрічається поєднання вагінального кандидозу і бактеріального вагінозу, при якому дріжджоподібні гриби беруть участь у полімікробних асоціаціях як збудники захворювання. Гриби роду Candida виявляють на тлі масивної кількості (понад 10 в 4 ступені КУО / мл) облігатно-анаеробних бактерій і гарднерел при різкому зниженні або відсутності лактобацил. Трихомонадний вагініт - вагініт, викликаний патогенними мікроорганізмами Trichomonas vaginalis, відноситься до захворювань, що передаються статевим шляхом. Для нього характерні запалення вульви і піхви, рясні пінисті виділення жовто-зеленого кольору з неприємним запахом, свербіж, печіння, дизурія, диспареунія. Вираженість клінічних ознак різна: від безсимптомного носійства (40 \%) до яскраво виражених проявів захворювання. При трихомонадному вагініті в мазках виявляють трихомонади (70 \%), велику кількість лейкоцитів. При вагінітах змішаної етіології найчастіше специфічні клінічні ознаки відсутні, не завжди вони чітко виражені при моноетіологічних вагінітах. Тому з метою ідентиорікації збудника і призначення адекватної терапії діагноз вагінальної інфекції повинен базуватися на результатах лабораторного дослідження, а у всіх випадках гнійного вагініту неясної етіології показано бактеріологічне дослідження. Діагностичні критерії і варіанти терапії для цих патологічних станів абсолютно різні і затверджені науковим товариством, в той час як інші патологічні стани вагінальної екосистеми потребують подальшого вивчення.

У 2001 році G. G. Donders у співавторстві запропонували термін «аеробний вагініт», щоб ідентисрікувати новий, не класифрікований патологічний стан, який не $є$ ні специфічним вагінітом, ні бактеріальним вагінозом. Такого висновку вчені дійшли на основі бактеріологічних та імунологічних досліджень, а також особливостей клінічної симптоматики [3, 4]. Аеробний вагініт (AB) - це інфекційно-запальне захворювання піхви і вульви, зумовлене дією виключно аеробних умовно-патогенних мікроорганізмів, що відрізняється від бактеріального вагінозу. На мікробіо- 
логічному рівні $\mathrm{AB}$ не супроводжується ростом анаеробної мікрофлори, тоді як значною мірою спостерігається збільшення частоти виділення грампозитивних коків: Streptococcus agalactiae (особливо стрептококи групи B), Staphylococcus aureus, Enterococcus spp. і грамнегативних мікроорганізмів роду Enterobacteriaceae, особливо Escherichia coli. Усі ці мікроорганізми мають кишкове походження і колонізують піхву, призводячи до зміни мікробіоценозу. На відміну від БВ, для аеробного вагініту характерна гіперемія слизової оболонки піхви, жовтого кольору виділення, свербіж та прояви диспареунії [3].

При лабораторному обстеженні спостерігається помірний дефріцит лактобактерій, наявність лейкоцитів (гранулоцитів) у піхвових виділеннях (10 і більше лейкоцитів на одну епітеліальну клітину), парабазальні епітеліальні клітини. Концентрація молочної кислоти знижена, як при бактеріальному вагінозі, проте, на відміну від нього, не виробляється сукцинат. Крім цього, виявляється негативний амінотест. При аеробному вагініті має місце виражена імунна відповідь, що полягає у високих концентраціях інтерлейкіну-6, інтерлейкіну-1ß, чого ніколи не спостерігається при БВ. Встановлено, що аеробний вагініт може стати більш вагомим фрактором ризику, ніж БВ, у відношенні акушерських ускладнень, таких, як хоріоамніоніт, передчасний розрив плодових оболонок, передчасні пологи [5].

Можна передбачити, що від аеробного вагініту страждає майже кожна п'ята-шоста гінекологічна пацієнтка, оскільки це захворювання найбільш поширена інфекція у жінок репродуктивного віку і $є$ не чим інакшим, як неспецисрічний вагініт, описаний Гарднером і Дюком ще у 1953 році. Після БВ, вульвовагінального кандидозу і трихомонозу АВ займає місце у структурі всіх інфекційно-запальних захворювань нижнього відділу жіночих статевих органів [4].

У розвитку вагінітів мікробний фрактор має таке ж важливе значення, як обставини, що змінюють його імунологічні властивості. До фракторів ризику відносять порушення обміну речовин, загальні інфекційні захворювання, хронічні стресові стани, токсичну дію деяких лікарських препаратів (антибіотики, цитостатики, антациди, глюкокортикоїди), різноманітні екстрагенітальні захворювання, аліментарний фактор, високу сексуальну активність.

Серед вагінітів все частіше виявляються полімікробні процеси (так звані мікст-інсрекції), при яких етіологічним фактором $€$ асоціація різних мікроорганізмів 3 характерними лише їй біологічними властивостями. Самі по собі вагініти не мають прямої загрози життю і здоров'ю пацієнтки, проте їх ускладнення і наслідки можуть значно нашкодити пацієнтам. У зв'язку з цим раціональне і ефрективне лікування запальних захворювань жіночих статевих органів складають непросте і надзвичайно актуальне завдання.

Терапія вагінітів спрямована на елімінацію патогенних мікроорганізмів і відновлення біоценозу піхви, що передбачає при цьому виключення негативного впливу на організм антимікробних засобів. Локальний шлях введення лікарських засобів дозволяє знизити фармакологічне навантаження на організм жінки. Його перевагою $є$ простота і зручність застосування, відсутність абсолютних протипоказань (окрім індивідуальної непереносимості компонентів препарату). Відповідно, для лікування вагінітів найбільш раціональним є місцеве застосування препаратів 3 широким спектром антимікробної дії, що найбільш повноцінно деконтамінують слизову оболонку. Окрім того, під час лікування вагініту необхідно забезпечити виключення провокуючих чинників, до яких відносять: антибіотикотерапію, застосування кортикостероїдів, тривалу внутрішньоматкову контрацепцію, гігієнічні фрактори, сексуальну активність тощо. Необхідно враховувати, що ендокринні, гематологічні та онкологічні захворювання сприяють зниженню імунореактивності організму в цілому і місцевих сракторів захисту, що також провокує розвиток вагінітів. При неадекватному лікуванні виникають рецидиви захворювань, що здійснює негативний вплив на репродуктивне здоров'я жінок і сприяє розвитку гінекологічних (запальних захворювань органів малого таза) і акушерських ускладнень (хоріоамніоніт, передчасні пологи та ін.). Наявність в арсеналі препаратів, що являють собою комбіновані протимікробні засоби, дозволяє клініцистам забезпечити ранній початок терапії даної групи пацієнтів - при необхідності після первинного огляду (до лабораторного підтвердження діагнозу). Тому застосування комплексних препаратів, есрективних при основних видах вагінальних інсекцій (бактеріальний вагіноз, трихомонадний і кандидозний та аеробний вагініти), є найбільш раціональним для успішного лікування. Фармацевтична компанія FARMAPRIM, Республіка Молдова, розробила лікарський засіб «Кломезол» у формі вагінальних супозиторіїв, добре відомий у країнах СНД, на сьогодні препарат зареєстрований і в Україні і застосовується для місцевої комбінованої терапії вагінітів різної етіології.

МЕТА ДОСЛІДЖЕННЯ - оцінити клінічну та мікробіологічну ефективність і безпечність застосування препарату «Кломезол» у лікуванні неспецифічного вагініту, а також провести порівняльну оцінку ефективності та оцінити ступінь безпечності застосування препаратів «Кломезол» і «Тержинан» у лікуванні вагінітів.

МАТЕРІАЛИ ТА МЕТОДИ. Наукове дослідження проводилось на базі Сумського обласного клінічного перинатального центру протягом 2016-2017 років. Для вирішення поставлених завдань було проведене обстеження і лікування 60 жінок репродуктивного віку (18-45 років) із встановленим діагнозом неспециорічного вагініту. Дослідження проведено відповідно до міжнародних нормативів і правил GCP. Пацієнтки, що відповідали чітко визначеним критеріям, були включені у дослідження після письмової згоди. Фактичне лікування, що призначали хворим, визначали шляхом чіткої послідовності на основі випадкової вибірки. Всі пацієнтки були розділені на 2 групи залежно від препарату, що призначався: 1-ша група (n=30) - кломезол; 2-га група $(n=30)$ - тержинан. Групова характеристика пацієнток подана в таблиці 1.

Групи були стратифріковані між собою на початковому етапі дослідження (під час першого візиту) за клінічними проявами захворювання, такими, як: характер виділень, запах, свербіж, біль, печіння, гіперемія слизової оболонки, ознаки диспареунії, а також за результатами лабораторних (мікроскопічних, кольпоцитологічних, біохімічних) методів дослідження, що дозволило порівнювати групи між собою. Статистично достовірна різниця відмічена лише по віку обстежуваних пацієнток $(p=0,01)$, що не мало принципового значення і не впливало на результати дослідження. 
Акушерство та гінекологія -

Таблиця 1. Загальна характеристика обстежуваних хворих

\begin{tabular}{|c|c|c|c|c|}
\hline \multirow{2}{*}{ Ознака } & \multicolumn{2}{|c|}{ Досліджувана група, $\chi^{2} \pm \sigma$} & \multirow{2}{*}{$\mathrm{p}$} & \multirow{2}{*}{ Критерій } \\
\hline & $I(n=30)$ & II $(n=30)$ & & \\
\hline Вік, років & $24,4 \pm 4,7$ & $29,2 \pm 7,9$ & 0,01 & \multirow[t]{7}{*}{ Манна - Уітні } \\
\hline Вага, кг & $62,8 \pm 5,2$ & $62,6 \pm 5,8$ & 0,8 & \\
\hline Зріст, см & $161,5 \pm 19,9$ & $161,6 \pm 20,2$ & 0,9 & \\
\hline Менархе, років & $12,1 \pm 1,2$ & $12,5 \pm 0,7$ & 0,07 & \\
\hline Паритет & $1,4 \pm 1,2$ & $1,4 \pm 2,1$ & 0,2 & \\
\hline Пологи & $0,4 \pm 0,7$ & $0,6 \pm 0,9$ & 0,2 & \\
\hline Аборти & $1,0 \pm 0,9$ & $0,7 \pm 1,3$ & 0,03 & \\
\hline
\end{tabular}

Критеріями включення у дослідження були: вік жінок від 18 до 45 років, наявність діагнозу «аеробний (неспецифрічний) вагініт». Критеріями виключення були: наявність вагітності та лактації, гострі чи хронічні запальні (у стадії загострення) захворювання малого таза, супутні іноекції, що передаються статевим шляхом (ІПСШ) - сифріліс, гонорея, хламідіоз, трихомоноз, гострокінцеві кондиломи, генітальний герпес, підвищена чутливість до компонентів препарату.

Пацієнтки, котрі були включені у дослідження, підлягали ретельному медичному обстеженню за 2-3 дні перед початком лікування.

Препарати «Кломезол» і «Тержинан» призначали відповідно до інструкції по медичному застосуванню препарату. Кломезол призначали по 1 супозиторію на ніч та вранці протягом 7 днів. При рецидивуючих вагінітах курс лікування кломезолом продовжували до 14 днів два рази на добу. Тержинан застосовували по 1 вагінальній таблетці 1 раз на добу протягом 10 днів.

У процесі лікування і після його закінчення через 2-3 дні (другий візит) для оцінки ефрективності та безпечності проведеної терапії вивчали клінічні симптоми неспецисрічного вагініту: гіперемію, набряк, болісність, наявність чи відсутність патологічних виділень; а також проводили рН-метрію вмісту піхви, амінотест і відбір проб вагінального ексудату для проведення мікроскопічних та культуральних досліджень. Бактеріологічні дослідження проводили у профрільних мікробіологічних лабораторіях 3 використанням стандартних культуральних методів дослідження. Посіви для бактеріологічної оцінки отримували не пізніше ніж за 3 дні до початку лікування. Матеріалом для дослідження вважався вагінальний вміст із заднього склепіння. Повторне обстеження проводили після закінчення лікування. Оцінку стану фуннціональної активності епітелію піхви проводили за даними кольпоцитологічного дослідження та ШИК-реакції.

Статистичну обробку результатів здійснювали за допомогою програми «Startistica 6,0». Використовували непараметричні методи. Розраховували середні, відносні величини. Для порівняння величин використовували критерії $\chi^{2}$, двобічний точний Фішера, Манна - Уітні.

РЕЗУЛЬТАТИ ДОСЛІДЖЕННЯ ТА ЇХ ОБГОВОРЕННЯ. Всі хворі до початку лікування скаржились на рясні виділення, причому у 2 (6,66 \%) жінок II групи ці виділення мали сироподібний характер, решта 28 (93,3\%) пацієнток мали пінисті виділення. У I групі 3 (10 \%) пацієнтки скаржились на сироподібні виділення, решта 27 (90 \%) пацієнток відмічали наявність виділень пінистого характеру. В процесі лікування відмічена позитивна динаміка і кількість виділень у пацієнток обох груп зменшувалась і до третього візиту у 30 (100 \%) пацієнток I і 28 (93,3 \%) жінок II групи виділення були незначними і мали слизовий характер.

При вивченні фрункціональної активності вагінального епітелію відмічено, що до початку лікування у 5 (16,6 \%) Хворих у I групі і у 9 (30 \%) жінок II групи спостерігалась слабка, у 15 (50 \%) у I і у 21 (70 \%) у II групі дуже слабка шИК-реакція. У 10 (33,3 \%) хворих I групи встановлена негативна ШИК-реакція. У II групі пацієнток із негативною реакцією не було. Різниця між групами статистично достовірна (табл. 2).

При кольпоцитологічному дослідженні у 15 (50\%) хворих I групи і у 19 (63,3 \%) хворих II групи виявлений КПІ, що відповідав фразі менструального циклу. У І групі в 1 (3,3 \%) хворої і у 2 (6,6 \%) хворих II групи виявлений еозинофрільний індекс (EI), у 3 (10,0 \%) хворих I групи і у 5 $(16,6$ \%) II групи виявлений індекс складчастості (Іскл.), в 11 (36,6 \%) у I групі виявлений індекс скупченості (ІСкуп.). У 4 (13,3\%) у II групі виявлений індекс поверхневих клітин (ІПК). Дані показники є статистично достовірними, що опосередковано відображає гестагенний вплив на епітелій піхви. Ці дані свідчать про більш достовірне зниження вихідної фуннцціональної активності вагінального епітелію у жінок I групи порівняно 3 II групою.

Під час другого візиту після лікування при забарвленні люголем у 16 (53,4 \%) хворих I групи і у 17 (56,6 \%) у II групі спостерігається інтенсивна ШИК-реакція, у 14 (46,6 \%) у I групі і у 13 (43,3 \%) у II групі спостерігалась помірна шиК-реакція. Слабкої і негативної шИК-реакції в обох групах не було виявлено. Різниця між обома групами статистично недостовірна (табл. 3).

Результати дослідження свідчать про покращення функціональної активності вагінального епітелію в результаті лікування жінок обох груп за рахунок пригнічення запальної реакції вагінального епітелію під впливом на умовно-патогенну мікрофрлору. Проте при кольпоцитологічному дослідженні виявлено, що у 12 (40,0 \%) хворих I групи і у $9(30,0 \%)$ жінок II групи виявлений КПІ, що відповідає фразі менструального циклу. В 1 (3,3 \%) хворих I групи і у 9 $(30,0 \%)$ хворих II групи виявлена статистична різниця по El $(p=0,01)$, що опосередковано свідчить про більшу естрогенну насиченість, тобто більшу концентрацію глікогену у клітинах вагінального епітелію та кращу їх функціональну активність у жінок I групи. В 11 (36,6 \%) хворих I групи і у 7 (23,3 \%) у II групі виявлений ІСкл., у 6 (20 \%) у I групі і у 5 (16,6 \%) у II групі виявлений індекс поверхневих клітин.

Вже через місяць після закінчення лікування відмічалась ШИК-позитивна реакція, що свідчила про високу фрункціональну активність вагінального епітелію, і відмі- 
Таблиця 2. Стан фрункціональної активності вагінального епітелію до початку лікування

\begin{tabular}{|c|c|c|c|c|c|c|}
\hline \multirow{3}{*}{ Ознака } & \multicolumn{4}{|c|}{ Досліджувана група } & \multirow{3}{*}{$\mathrm{p}$} & \multirow{3}{*}{ Критерій } \\
\hline & \multicolumn{2}{|c|}{$I(n=30)$} & \multicolumn{2}{|c|}{ II $(n=30)$} & & \\
\hline & абс. число & $\%$ & абс. число & $\%$ & & \\
\hline \multicolumn{7}{|c|}{ шиК-реакція } \\
\hline Інтенсивна & 0 & 0,0 & 0 & 0,0 & \multirow{5}{*}{0,002} & \multirow{5}{*}{$x^{2}$} \\
\hline Помірна & 0 & 0,0 & 0 & 0,0 & & \\
\hline Слабка & 5 & 16,6 & 9 & 30,0 & & \\
\hline Дуже слабка & 15 & 50,0 & 21 & 70,0 & & \\
\hline Негативна & 10 & 33,3 & 0 & 0,0 & & \\
\hline \multicolumn{7}{|c|}{ Кольпоцитологія } \\
\hline КП। & 15 & 50,0 & 19 & 63,3 & 0,6 & \multirow{5}{*}{ Фішер } \\
\hline El & 1 & 3,3 & 2 & 6,6 & 1,0 & \\
\hline ІСкл. & 3 & 10,0 & 5 & 16,6 & 0,7 & \\
\hline ІСкуп. & 11 & 36,6 & 0 & 0,0 & 0,0001 & \\
\hline ІІК & 0 & 0,0 & 4 & 13,3 & 0,1 & \\
\hline
\end{tabular}

КПІ - каріопікнотичний індекс; EI - еозинофрільний індекс; ІСкл. - індекс складчастості; ІСкуп. - індекс скупченості; ІПК - індекс поверхневих клітин.

Таблиця 3. Стан функціональної активності вагінального епітелію в процесі лікування

\begin{tabular}{|c|c|c|c|c|c|c|}
\hline \multirow{3}{*}{ Ознака } & \multicolumn{4}{|c|}{ Досліджувана група } & \multirow{3}{*}{$\mathrm{p}$} & \multirow{3}{*}{ Критерій } \\
\hline & \multicolumn{2}{|c|}{ I $(n=30)$} & \multicolumn{2}{|c|}{ II $(n=30)$} & & \\
\hline & абс. число & $\%$ & абс. число & $\%$ & & \\
\hline \multicolumn{7}{|c|}{ ШИК-реакція } \\
\hline Інтенсивна & 16 & 53,4 & 17 & 56,6 & \multirow{5}{*}{1,0} & \multirow{5}{*}{ Фішер } \\
\hline Помірна & 14 & 46,6 & 13 & 43,3 & & \\
\hline Слабка & 0 & 0,0 & 0 & 0,0 & & \\
\hline Дуже слабка & 0 & 0,0 & 0 & 0,0 & & \\
\hline Негативна & 0 & 0,0 & 0 & 0,0 & & \\
\hline \multicolumn{7}{|c|}{ Кольпоцитологія } \\
\hline КП। & 12 & 40,0 & 9 & 30,0 & 0,5 & \multirow{5}{*}{ Фішер } \\
\hline El & 1 & 3,3 & 9 & 30,0 & 0,01 & \\
\hline IСКл. & 11 & 36,6 & 7 & 23,3 & 0,3 & \\
\hline ІСкуп. & 0 & 0,0 & 0 & 0,0 & 1,0 & \\
\hline IПК & 6 & 20,0 & 5 & 16,6 & 1,0 & \\
\hline
\end{tabular}

КПІ - каріопікнотичний індекс; EI - еозинофрільний індекс; ІСкл. - індекс складчастості; ІСкуп. - індекс скупченості; ІПК - індекс поверхневих клітин.

чена у всіх жінок I групи та у 26 (86,6 \%) у II групі, тут же в 1 (3,3\%) констатована помірна ШИК-реакція, у 2 (6,6 \%) - слабка ШИК-реакція і в однієї хворої - негативна, що пояснюється тенденцією повільнішого відновлення функціональної активності вагінального епітелію у групі жінок, котрі отримували тержинан у зв'язку з імуносупресивною дією преднізолону на слизову піхви.

При кольпоцитологічному дослідженні у 3 (10,0 \%) хворих I групи і у 5 (16,6 \%) жінок II групи КПІ відповідав фразі менструального циклу, у 11 (36,6 \%) у I групі виявлений El, у 4 (13,3 \%) хворих II групи виявлений ІСкл., у 16 (53,3 \%) хворих I групи виявлений ІСкл., у 21 (70,0 \%) в II групі виявлений ІПК. Різниця між групами достовірна, що підтверджує меншу негативну дію на фрункціональну активність ендометрію кломезолу порівняно з тержинаном.

Після закінчення лікування через 1 місяць проведена оцінка ефрективності лікування, відмінний ефект спостерігався у $23(76,7 \%)$ хворих, у $6(19,9 \%)$ жінок відмічений хороший ефект і в однієї пацієнтки $(3,4 \%)$ - задовільний есрект. У II групі у 19 (63,4 \%) хворих спостерігався відмінний ефект, хороший результат відмічений у 8 (26,6 \%) хворих, у 2 (6,6 \%) хворих спостерігався задовільний есрект і в однієї пацієнтки (3,4 \%) лікування було неефективним у зв'язку з виявленням при культуральних дослідженнях грибів роду Candida у значній кількості за відсутності клінічної симптоматики.

Окрім об'єктивного обстеження і суб'єктивної оцінки симптомів, проводили оцінку якості життя, в цілому відмічене покращення якості життя пацієнток обох груп у процесі лікування.

Небажаних результатів та побічних ефектів у процесі лікування пацієнток обох груп не виявлено. Результати терапії неспецифрічного вагініту кломезолом і тержинаном показали високу ефективність та безпечність обох препаратів. Достовірна різниця в динаміці відновлення лактофрлори і фрункціональної активності вагінального 
епітелію свідчить про більш виражений імуносупресивний есрект тержинану на слизову оболонку і мікробіоценоз піхви. Отримані результати дозволяють рекомендувати кломезол для лікування неспецифічного та змішаного вагінітів і запальних захворювань піхви.

ВИСНОВКИ. Таким чином, за результатами проведеного дослідження можна зробити такі висновки:

1. Кломезол $€$ ефрективним і безпечним препаратом у відношенні умовно-патогенних мікроорганізмів, збудників неспецифічних вагінітів, анаеробних кольпітів та вагінального кандидозу.

\section{СПИСОК ЛІТЕРАТУРИ}

1. Серов В. Н. Особенности инфекции в акушерстве, гинекологии и перинатологии / В. Н. Серов // Рус. мед. журн. - 2006. - T. 14, № 1. - С. 2-5.

2. Кира Е. Ф. Бактериальный вагиноз / Е. Ф. Кира. - СПб. : ООО «НеваЛюкс», 2001. - 364 с.

3. Aerobic vaginitis is an entity with abnormal vaginal flora that is distinct from bacterial vaginosis / G. G. Donders, A. Vereecken, E. Bosnians [et al.] // Int. J. STD AIDS. - 2001. Vol. 12, Suppl 2. - P. 68.

\section{REFERENCES}

1. Serov, V.N. (2006). Osobennosti infektsii v akusherstve, ginekologii i perinatologii [Features of infection in obstetrics, gynecology and perinatology]. Rus. med zhurn. - Russian Medical Journal, 14(1), 2-5 [in Russian].

2. Kira, E.F. (2001). Bakterialnyy vaginoz [Bacterial vaginosis]. Neva Luks [in Russian].

3. Donders, G.G., Vereecken A., \& Bosnians E. (2001). Aerobic vaginitis is an entity with abnormal vaginal flora that is distinct from bacterial vaginosis. Int. J. STD AIDS, 12(2), 68.
2. Кломезол є препаратом вибору при лікуванні неспецифрічних вагінітів, не здійснює імуносупресивного впливу на вагінальний епітелій, завдяки чому відновлення фрункціональної активності вагінального епітелію після лікування кломезолом проходить швидше, ніж після лікування тержинаном.

3. Після лікування відмічено покращення якості життя у пацієнток обох груп.

ПЕРСПЕКТИВИ ПОДАЛЬШИХ ДОСЛІДЖЕНЬ ПОлягають у поглибленні вивчення проблеми застосування кломезолу у пацієнток з вагінальними інфекційно-запальними процесами змішаного генезу.

4. Definition of a type of abnormal vaginal flora that is distinct from bacterial vaginosis: aerobic vaginitis / G. G. Donders, A. Vereecken, E. Bosmans [et al.] // BJOG. - 2002. - Vol. 109, № 1. - P. 34-43.

5. Predective value for preterm birth of abnormal vaginal flora, bacterial vaginosis and aerobic vaginitis during the first trimester of pregnancy or why metronidasole is not a good option in pregnancy / G. G. Donders, C. Van Calsteren, G. Bellen [et al.] // 6th European Conference ESIDOG / Abstract Book. -2008 . Plen II-2.

4. Donders, G.G., Vereecken, A., \& Bosmans, E. (2002). Definition of a type of abnormal vaginal flora that is distinct from bacterial vaginosis: aerobic vaginitis. BJOG,109(1), 34-43.

5. Donders, G.G., Van Calsteren, C., \& Bellen, G. (2008) Predective value for preterm birth of abnormal vaginal flora, bacterial vaginosis and aerobic vaginitis during the first trimester of pregnancy or why metronidasole is not a good option in pregnancy. $6^{\text {th }}$ European Conference ESIDOG / Abstract Book. Plen II-2. 